\title{
Application of Slow Sand Filters
}

ISSN: 2637-7659

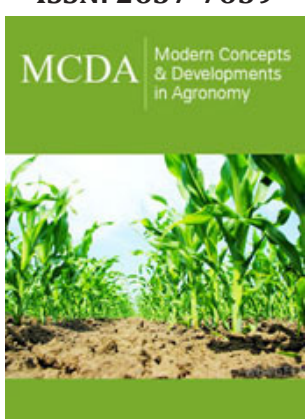

*Corresponding author: Carlos Modesto Martínez Hernández, Dr. C. Prof. Titular, Universidad Central "Marta Abreu"de las Villas, Carretera a Camajuaní Km.5.5. CP: 54830, Santa Clara, Villa Clara, Cuba

Submission: 烝 September 06, 2021

Published: 㭗September 16, 2021

Volume 9 - Issue 3

How to cite this article: Carlos Modesto Martínez Hernández. Application of Slow Sand Filters. Mod Concep Dev Agrono. 9(3). MCDA. 000715. 2021. DOI: 10.31031/MCDA.2021.09.000715

Copyright@ Carlos Modesto Martínez Hernández. This article is distributed under the terms of the Creative Commons Attribution 4.0 International License, which permits unrestricted use and redistribution provided that the original author and source are credited.
Carlos Modesto Martínez Hernández*

Dr. C. Prof. Titular, Universidad Central “Marta Abreu”de las Villas, Cuba

\section{Opinion}

In the last years we had worked in the use of slow sand filters for the decontamination of biodigesters effluents and the sugar mill oxidation lagoons. The work was carried out with the objective of eliminating the contamination of these effluents located in some sugar mills as: "Carlos Baliño", “George Washington" and "Melanio Hernández". The effluents were taken in the central region of Cuba (Santo Domingo, Manacas, Villa Clara and Tuinicú, Sancti Spíritus). The effluents were proven to passing through by the slow sand filter in cascades before different investigated treatments. The effluents were diluted in distilled water in the different proportions: T1 (10\%), T2 (25\%), T3 (50\%), T4 (75\%), T5 and T6 (not diluted). In the effluents, they were determined: their physical-chemical and microbiological characteristics, previous and later to passing through by the slow sand filters. In most of the effluents, so much their physical-chemical properties, like as the microbial load a remarkable reduction was obtained; obtaining values which are in accordance with the Cuban norms [1-3]. The slow sand filtration has been broadly used as method to improve the quality of the water in different regions of the planet, due to its simplicity in the operation and to its numerous advantages. It has been demonstrated that the slow sand filters have worked in a successful way in areas so much urban as rural around the world, many of which subsist in a precarious way, allowing improvements as regards public health and in the quality of the inhabitants' life of these areas, even in it has been evidenced their good operation and the positive impact that generate this type of technologies. In recent investigations [4-10], it has been evaluated the method of slow sand filtration like alternative to obtain not very aggressive effluents of oxidation lagoons to the environment with local materials diminishing costs and offering an alternative before the current conditions of these effluents, which are poured to the means with high value of contamination. Some of these studies, they have referred to the implementation a slow sand filters systems to laboratory scale with the purpose of improving the effluents of oxidation lagoons, and later on to measure certain parameters of the effluents and to compare them with the Cuban norm [1] of residual water and [2] for the use of the residual of the sugar cane industry for to irrigate the sugar cane. In the investigations indexed previously, it has been able to verify that the slow sand filters were a good alternative to improve the quality of the biodigesters effluents, obtaining high percentages of removal of chemical oxygen demand (COD), biological oxygen demand (BOD5), total solids (TS), fecal coliform, total coliform and pseudomonas aeruginosas in recent investigations. On this base, this work had the main purpose of to evaluate the effect of slow sand filters for the improving the sugar mill oxidation lagoon effluents with different dilution percent's in water. For that reason, it is presented in a summarized way some of the obtained results:

A. A slight increase of the $\mathrm{pH}$ values was observed, in all the treatments, except in the $\mathrm{T} 4(7,36)$. The $\mathrm{pH}$ behaved in values that they oscillate between 7,36 and 8 , 82. According to its comparison with the Cuban Norm [2], the treatments T1 $(8,82)$ and T2 $(8,58)$ they should not be used for its application to irrigate sugar cane; In the electric conductivity (E.C) one could observe that the treatments T2 $(1,07), \mathrm{T} 4(1,08), \mathrm{T} 5(0,6)$ and T6 (1), 
classified as good later to passing through for the slow sand filters, they comply the Cuban norm [2]. Not being this way in the cases of the treatments $\mathrm{T} 1(1,70)$ and $\mathrm{T} 3(1,56)$, classified as regular. This indicator behaved inside the range of 0,6 and 1 , $70 \mu \mathrm{S} / \mathrm{cm}$, reducing the saline content of the effluents notably.

B. In the case of the variable total soluble salts (TSS), an increase was presented from 363 up to $895 \mathrm{mg} \mathrm{L}^{-1}$ as the degree of dilution was increased, but in all the cases that was fulfillment the Cuban norm [2] that limits it to $<960 \mathrm{mg} \mathrm{L}^{-1}$ even for the not diluted sample.

C. The temperature of the water of the effluents of the "Melanio Hernández" they diminish from 28,8 up to $27,0\left({ }^{\circ} \mathrm{C}\right)$; while the effluents of the "Carlos Baliño" after the filtrate process they oscillate between 25,8 and $23,6\left({ }^{\circ} \mathrm{C}\right)$, allowing to improve the quality of these, the COD began to vary moderately from 177 to $73 \mathrm{mg} \mathrm{L}^{-1}$ being smaller than the settled dawn for the [1] that limits it to $<700 \mathrm{mg} \mathrm{L}^{-1}$.

D. In the B0D5 a notorious decrease was observed from $88 \mathrm{mg} \mathrm{L}-1$ to $36 \mathrm{mg} \mathrm{L}^{-1}$, complying that specified by the [1] that limits it to $<300 \mathrm{mg} \mathrm{L}^{-1}$.

E. The treatment systems used slow sand filters allow to diminish the polluting load of the residual and they increase the efficiency as this it is filtered, allowing their poured and use with economic ends.

F. An amplification of this mini revision will be consulted in the next papers that will be published of the Cuban magazine Titled: “Ciencias Técnicas Agropecuarias” and "Centro Agrícola”.

\section{References}

1. NC-27 (2012) Evolution environmental in areas affected by pollution, caused by santa lucia mineral deposit, Pinar el Rio. Especificaciones. ININ/ Oficina Nacional de Normalización. La Habana, Cuba, p. 11.
2. NC-855 (2011) Utilización de las aguas residuales de la industria azucarera y de derivados en el fertirriego de la caña de azúcar. ININ/ Oficina Nacional de Normalización, La Habana, Cuba, p. 13.

3. NC-1095 (2015) Microbiología del agua. Detección y enumeración de coliforms, Técnicas del número más probable (NMP). Oficina Nacional de Normalización (NC), La Habana, Cuba, p. 23.

4. Brito A, Delgado 0, Villarreal M (2019) Evaluación de los residuales generados en el sistema de tratamiento del integral porcino \# 1. Reporte de investigación. Cienfuegos, Cuba, p. 9.

5. Francesena Y (2016) Impacto ambiental provocado por efluentes de instalaciones de biogás de pequeña y mediana escala en las provincias de la región central de Cuba. Trabajo de diploma (en opción al título de Ingeniero Agrícola). UCLV, Cuba, p. 51.

6. Fabregat J (2019) Treatment and use of effluents from pig biodigesters as organic fertilizers. Trabajo de diploma (en opción al título de Ingeniero Agrícola). UCLV, Cuba, p. 64.

7. Llama DA (2019) Evaluation of the effect of the slow sand filter for the treatment of effluents from oxidation lagoons in the UCLV, Central University of Las Villas UCLV, Diploma Work (in option to the title of Hydraulic Engineer), Santa Clara, Villa Clara, Cuba, p. 54.

8. Sánchez J (2020) Use of effluents from oxidation lagoons of the CAI "Carlos Baliño" as organic fertilizers, Central University of Las Villas UCLV Faculty of Agricultural Sciences, Diploma work (in option to the title of Agricultural Engineer), Santa Clara, Villa Clara, Cuba, p. 92.

9. Villareal VM (2017) Evaluation of local materials in the manufacture of filters for drinking water treatment. Trabajo de diploma (en opción al título de Ingeniero Hidráulico). Universidad Central "Marta Abreu" de Las Villas, Cuba, p. 57.

10. Ramírez E (2021) Análisis del efluente del CAI "George Washington" para su posible uso como abono orgánico. Trabajo de Diploma (en opción al título de Ing. Agrícola), UCLV, Cuba, p. 109. 